\title{
Increase in Fermentable Sugars of Olive Tree Pruning Biomass for Bioethanol Production: Application of an Experimental Design for Optimization of Alkaline Pretreatment
}

\author{
Arminda Mamaní1,3*, Yolanda Maturano ${ }^{2,3}$, Laura Herrero ${ }^{1,3}$, Laura Montoro ${ }^{1,3}$, Fabiana Sardella ${ }^{1}$ \\ 1 Institute of Chemical Engineering, Faculty of Engineering, National University of San Juan, Av. Libertador 1109, J5400 San Juan, \\ Argentina \\ 2 Biotechnology Institute, Faculty of Engineering, National University of San Juan, Av. Libertador 1109, J5400 San Juan, Argentina \\ ${ }^{3}$ National Council of Scientific and Technical Research (CONICET), Godoy Cruz 2290, C1425FQB Buenos Aires, Argentina \\ *Corresponding author, e-mail: mamani@unsj.edu.ar
}

Received: 22 March 2021, Accepted: 22 July 2021, Published online: 12 January 2022

\begin{abstract}
Olive Tree Pruning (OTP) biomass can be considered a suitable source of fermentable sugars for the production of second-generation bioethanol. The present study proposes a remarkable alternative for the valorization of olive tree pruning residues. OTP biomass was processed using a sequential calcium hydroxide pretreatment/enzymatic hydrolysis. A $2^{4-1}$ half fractional factorial design was adopted for the screening of process variables and a central composite design was used for the optimization stage. Temperature and lime loading resulted statistically significant. The following optimal conditions were obtained: $0.01 \mathrm{~g}$ of $\mathrm{Ca}(\mathrm{OH})_{2} / \mathrm{g}$ of $\mathrm{dry}$ material, $20 \mathrm{~g}$ of $\mathrm{H}_{2} \mathrm{O} / \mathrm{g}$ of dry material at $160^{\circ} \mathrm{C}$ for $2 \mathrm{~h}$. The mathematical model that governs this alkaline pretreatment was obtained with a $76 \%$ adjusted determination coefficient, which means that it is a good representation of the process. Under optimal operating conditions, $13 \%$ of the cellulose and $88 \%$ of the hemicellulose was solubilized. Moreover, the fermentable sugar content increased $1800 \%$ compared with the initial conditions, obtaining $240 \mathrm{~g}$ of glucose per $\mathrm{kg}$ of OTP residue. The fermentable sugars obtained after the calcium hydroxide pretreatment and enzymatic hydrolysis of OTP biomass yielded $2.8 \mathrm{~g}$ of ethanol/100 $\mathrm{g}$ of raw material.
\end{abstract}

Keywords

Olive Tree Pruning (OTP), calcium hydroxide pretreatment, optimum conditions, fermentable sugars, bioethanol

\section{Introduction}

Energy policies that have been implemented in recent years are oriented towards the exploitation of renewable energy sources, greatly encouraged by economic and tax incentives [1]. These policies are leading to significant changes through the combination of different types of energy, progressively replacing conventional fuels by renewable energy sources. Worldwide, countries intend to reach objectives on renewable energies with a relevant paradigm change in the exploitation of renewable sources [2]. These sources do not generate hazardous waste and help reduce the greenhouse effect. Lignocellulosic materials have been proposed within the concept of precursors for a wide range of value-added products [3]. This concept also stimulates the participation of agriculture and involves energy recovery from waste [4]. The residues generated during olive cultivation, e.g. during tree pruning, are lignocellulose-rich raw materials and abundant. Currently, about 11 million hectares in the world are cultured with olive trees, with an estimated annual Olive Tree Pruning (OTP) biomass production of $3000 \mathrm{~kg} / \mathrm{ha}$ [5]. Removal of olive tree pruning biomass is necessary to keep clean fields and to avoid propagation of plant diseases or burning practices, which cause air pollution. Moreover, its great abundance, low cost and lignocellulosic composition, make this residue appropriate as a renewable energy source, with many environmental advantages $[3,6]$.

Second generation bioethanol is obtained from raw materials (lignocellulosic material) that have no negative impact on the food chain [7]. Conversion into ethanol generally includes four steps: pretreatment, hydrolysis, fermentation and product recovery [8]. Pretreatment is the most complicated and expensive step. Cellulose is usually sheathed by hemicelluloses forming a cellulose-hemicellulose complex that works as a chemical barrier and prevents 
access of enzymes to the complex under natural conditions [9]. In addition, the cellulose-hemicellulose complex is encapsulated with lignin and this structure limits enzymatic hydrolysis of biomass to produce fermentable sugars [10]. Therefore, a pretreatment is required to remove the lignin-cellulose-hemicellulose complexes through changes in the macroscopic, submicroscopic and microscopic structures of the biomass, making it accessible to the hydrolytic enzymes that convert cellulose and hemicellulose into fermentable sugars [11]. Pretreatments can be roughly classified into four groups: physical, chemical, physicochemical and biological techniques [8]. Numerous different pretreatments have been carried out with a wide range of lignocellulosic biomasses to determine the most appropriate method and special requirements of each biomass [12]. Within chemical pretreatments, different substances and conditions have been assayed [13]. For example, alkaline pretreatments do not require extreme conditions such as high temperature and high pressure [14]. Hydroxide has been used as an alkaline pretreatment with significant advantages over others, as it is cheap and safe to handle [15]. Pretreatment with $\mathrm{Ca}(\mathrm{OH})_{2}$ generally avoids significant loss of carbohydrates. A disadvantage is its poor solubility, but this can be solved by varying the operating conditions [16, 17]. Pretreatments with $\mathrm{Ca}(\mathrm{OH})_{2}$ have been studied using rice straw, switch grass, sugarcane bagasse, corn stover and wheat straw [18]. Presently, there are no reports on $\mathrm{Ca}(\mathrm{OH})_{2}$ pretreatment of olive tree pruning biomass assessing a set of procedures that support the statistical analysis of different experiments. Factorial designs, based on a combination of factors, are classical experimental designs that have been widely used in scientific experiments to simultaneously examine multiple factors and their interactions while reducing the degree of bias in the experiments [19].

The main goal of the present study was valorization of Olive Tree Pruning residues by its use for bioethanol production. The study is focused on the use of an alkaline treatment with lime, a low cost reagent, under mild conditions, to remove lignin without degrading carbohydrates, increasing the porosity of the raw material and enhancing enzymatic hydrolysis of Olive Tree Pruning residues. The operating conditions were optimized using a half fraction factorial experimental design and a composite central design. It proposes a simple operation scheme with a less aggressive chemical reagent, leading to environmental and economic advantages, due to a lower energetic demand and equipment investment. Besides, it presents an evaluation of the use of native yeasts, isolated from the wine process, in the fermentation stage, an innovation thought under the circular economy concept, for a region where agribusiness is one of the main economic activities.

\section{Materials and methods}

\subsection{Material collection and preparation}

Branches and leaves were collected during March and April 2019 after olive tree pruning (Olea europaea) in San Juan province, Argentina ( $\left.31^{\circ} 41^{\prime} 00^{\prime \prime} \mathrm{S} ; 68^{\circ} 35^{\prime} 00^{\prime \prime} \mathrm{W}\right)$. Samples were washed with tap water to remove contaminants and placed in direct sunlight at ambient temperature for 7 days. The dried material was ground and sieved to the desired particle size for each analysis.

\subsection{Material characterization}

Moisture content $(\%)$ was determined by drying at $105 \pm 3{ }^{\circ} \mathrm{C}$ for $3 \mathrm{~h}$ and calculated as the percentage of mass loss (ASTM D4442-92 [20]). Moisture, Total Solids (TS) and ash content were calculated as weight percentage. To determine the ash content, samples were placed in crucibles which were located in a muffle furnace at $575{ }^{\circ} \mathrm{C}$ until carbon was completely eliminated (ASTM D1102-84 [21]). Volatile Matter (VM) was estimated using a muffle furnace at $950{ }^{\circ} \mathrm{C}$ for 7 min (ASTM E872-82 [22]). Fixed Carbon (FC) was calculated through the difference in moisture percentage between ash and volatiles. Total sugars were determined using the Dubois method [23], a spectrophotometric technique that involves the reaction of sugars with phenol and sulfuric acid to form a colored compound. The percentage of cellulose, hemicellulose, and lignin was calculated from Neutral Detergent Fiber (NDF), Acid Detergent Fiber (ADF), and Acid Detergent Lignin (ADL) using Eqs. (1)-(3).

$\%$ Lignin $=\% \mathrm{ADL}$

$\%$ Cellulose $=\% \mathrm{ADF}-\% \mathrm{ADL}$

$\%$ Hemicellulose $=\% \mathrm{NDF}-\% \mathrm{ADF}$

\subsection{Calcium hydroxide pretreatment}

OTP biomass was ground and sieved to a particle size below $1.4 \mathrm{~mm}$, and then contacted with different volumes of distilled water and high purity calcium hydroxide in a 1 liter Parr reactor. Different reaction times were assayed under constant stirring and automatic temperature control. Pretreatment stages were performed according to two 
experimental designs; one for screening variables and one for optimization of these variables. Commercial software (Design-Expert 11.0.3) was used to analyze the results and optimize the conditions.

\subsubsection{Screening design}

The following variables were assayed: temperature (40$\left.120^{\circ} \mathrm{C}\right)$, lime loading $\left(0.05-0.5 \mathrm{~g} \mathrm{Ca}(\mathrm{OH})_{2} / \mathrm{g}\right.$ of dry mass), water loading (10-20 $\mathrm{g} \mathrm{H}_{2} \mathrm{O} / \mathrm{g}$ of dry mass), and pretreatment time (120-480 min), according to a $2^{4-1}$ half fractional factorial design. A total of 18 experiments, including four central point experiments, were performed. The reducing sugar content, determined by the DNS method, was chosen as response variable to evaluate the effect of the alkaline pretreatment.

\subsubsection{Optimization design}

RMS analysis was employed to determine the effects of different operating factors on the reducing sugar content and reveal the optimum conditions to increase this value, this technique was also used to build models. The effects of the screened variables, obtained with the screening experimental design, on the increase in reducing sugars were assayed to optimize the pretreatment process. The objective was to maximize the content of reducing sugars. The following two variables were optimized: temperature (100-220 ${ }^{\circ} \mathrm{C}$ ) and lime loading (0.005-0.015 g Ca(OH) $/ \mathrm{g}$ of dry mass) according to a rotatable central composite design with a total of 11 experiments. Four star points, distributed at a distance of 1.4 from the central point, and two central points were included to gather important information on the reproducibility of the experiments and on the suitability of the proposed model [24]. The response variable was the reducing sugar content.

\subsection{Enzymatic hydrolysis}

Pretreated biomass was subjected to enzymatic hydrolysis to examine the effect of different pretreatment conditions on the enzymatic digestibility. Hydrolysis of all pretreated samples and raw material was performed using a mixture of two enzymes: cellulase from Trichoderma reesei ATCC 26921 ( $\geq 700$ units/g) (Sigma Aldrich, Denmark) and hemicellulase from Aspergillus niger (0.3-3 units/mg) (Sigma Aldrich, USA). Enzymes were suspended in 0.05M sodium citrate buffer ( $\mathrm{pH}$ 4.9). Enzymatic hydrolysis was carried out in a rotary shaker at $45{ }^{\circ} \mathrm{C}$ for $24 \mathrm{~h}$, with a rotational speed of $100 \mathrm{rpm}$ and at a substrate concentration of $4 \%(\mathrm{w} / \mathrm{v})$. All experiments were performed in duplicate.
A small aliquot of hydrolysate was taken from each sample to determine reducing sugars according to the method aforementioned.

\subsection{Validation of the statistical model}

Statistical analysis is useful for optimum operating conditions to obtain maximum fermentable sugar content and to build models. Validation of the statistical model is a fundamental step to ensure reliable results. The screening and optimization designs provided models that show the mathematic relationship between the response variable (reducing sugars) and the variables assayed (temperature, lime loading, water loading and pretreatment time concerning the screening experimental design and lime loading and temperature to optimize the experimental design). These models can be described by Eqs. (4), (5):

$$
\begin{aligned}
& Y=\alpha_{0}+\alpha_{1} \times A+\alpha_{2} \times B+\alpha_{3} \times C+\alpha_{4} \times D+\alpha_{12} \times A \times B \\
& +\alpha_{13} \times A \times C+\alpha_{14} \times A \times D \\
& Y=\beta_{0}+\beta_{1} \times A+\beta_{2} \times B+\beta_{11} \times A^{2}+\beta_{22} \times B^{2},
\end{aligned}
$$

where $Y$ is the predicted response, $A, B, C$ and $D$ are the factors studied, and $\alpha_{i}$ and $\beta_{i}$ are coefficients estimated from regression analysis, which represent the linear, quadratic and cross-products of $A, B, C, D$ on the responses. The validity of the equations was analyzed with ANOVA, and the goodness of fit of the equations was judged with the determination coefficients of the $P$-value.

The validation step consisted in contrasting the experimental results of the response variable against the values predicted by the model. Besides, experimental assays were performed in triplicate under optimum conditions predicted with the model and this biomass is hereafter referred to as $\mathrm{OPH}$.

\subsection{Determination of pretreatment effects}

SEM was used to compare the surface of untreated and pretreated biomass. Samples were dried, coated with gold and examined with a JEOL JSM-6610LV (MEB) electron microscope. Analyses were performed at $100 \mu \mathrm{m}(250 \times$ magnification) and $5 \mu \mathrm{m}(3000 \times$ magnification). The specific surface area of untreated OTP biomass was determined through $\mathrm{N} 2$ adsorption isotherms at $-196.1{ }^{\circ} \mathrm{C}$ (Micromeritics ASAP-2000). Before adsorption analysis, samples were outgassed at $100{ }^{\circ} \mathrm{C}$ for $12 \mathrm{~h}$, and subsequently surface areas were determined using the BET theory. 


\subsection{Fermentation}

Fermentation assays were carried out in $25 \mathrm{~mL}$ test tubes, inoculating $10 \mathrm{~mL}$ of OPH biomass ( $\mathrm{pH} 4.9$ ) with $2 \times 10^{6}$ cells $/ \mathrm{ml}$ of Saccharomyces cerevisiae BSc114, a native yeast isolated from an enological environment in San Juan province. Tubes were overlaid with Vaselineparaffin, statically incubated at $28 \pm 2{ }^{\circ} \mathrm{C}$ and monitored for 3 days every $24 \mathrm{~h}$ for $\mathrm{CO}_{2}$ production. Assays were considered positive when the Vaseline-paraffin overlay was displaced. Positive tests were submitted to sugar [25] and ethanol determination. The production of ethanol was measured by Gas Chromatography (GC). Samples were taken from the supernatant, diluted, stirred, and filtered through a $0.45 \mu \mathrm{m}$ syringe filter (Microlar $26 \mathrm{~mm}$, nyl). Analysis of each sample was then carried with a SHIMADZU GC-2010 Plus gas chromatograph equipped with a Flame Ionisation Detector (FID) and a CHROMPACK column $(30 \mathrm{~m} \times 0.25 \mathrm{~mm}$ id, and $0.25 \mu \mathrm{m}$ film thickness). Nitrogen was used as carrier gas at a flow rate of $1 \mathrm{ml} / \mathrm{min}$. GC operation always started with an injector temperature and detector temperature set at $240{ }^{\circ} \mathrm{C}$ and $260{ }^{\circ} \mathrm{C}$, respectively and with a $1: 10$ split ratio. $0.1 \mu \mathrm{l}$ of each sample was injected, by triplicate, and the ethanol concentration was measured by maintaining the $\mathrm{GC}$ oven temperature at $35^{\circ} \mathrm{C}$, for 9.5 minutes.

\section{Results and discussion}

\subsection{Material characterization}

The physicochemical properties of the biomass are affected by handling, storage and transport facilities while the biomass composition determines the efficiency of the conversion from raw material into energy [26]. The amount of water in the raw material is represented by the moisture content, which is determined as the percentage of air-dried biomass weight. The OTP biomass assayed contained $7.64 \%$ water, suggesting an appropriate drying process and suitable storage conditions. Other parameters like TS, VM, FC and ash reported 92.36\%, 74.70\%, $12.36 \%$, and $5.30 \%$, respectively. NDF, ADF and ADL determined in air-dried biomass were $58.40 \%, 41.14 \%$ and $9.26 \%$, respectively. During NDF analysis it was possible to dissolve digestible cell contents such as sugar, starch, protein and pectin from the biomass and leave the fibrous residues [27]. The high NDF value obtained in our study showed that only $41 \%$ of OTP biomass consisted of soluble substances. Therefore, $58.40 \%$ of air-dried OTP biomass was solid, mainly composed of cellulose (31.88\%), hemicellulose $(17.26 \%)$ and lignin $(9.26 \%)$, the principal cell wall components. Consequently, alkaline pretreatment of OTP biomass under different conditions might be a suitable method to deal with the lignin barrier and dissolve carbohydrates.

\subsection{Calcium hydroxide pretreatment}

\subsubsection{Statistical analysis of the screening design}

Application of a $2^{4-1}$ half fractional factorial design to the pretreatment generated the following polynomial equation for reducing sugar content Eq. (6).

$$
\begin{aligned}
& \text { Red. Sugars } \\
& +\mathrm{mg} / \mathrm{g}) \\
& +0.02 \times D-0.57 \times A \times B, \quad R^{2}=0.9442
\end{aligned}
$$

The significance and adequacy of the regression model was tested with the $p$-value and the determination coefficient, and the corresponding results of the Analysis of Variance, ANOVA, are presented in Table 1. This test evidences the statistical significance of each effect comparing their mean square against an estimate of the experimental error. In our case three effects, temperature, lime loading and the interaction between both, showed $p$-value below the level of significance $\alpha=0.05$, indicating that they significantly affected the variation of the content of reducing sugars with a $95.0 \%$ confidence level. The very low $p$-value (less than 0.0001 ) obtained for the model suggests that it was highly significant for the pretreatment process. The fact that the value obtained for the lack of fit was insignificant means that the quadratic model was perfectly acceptable. Another evaluation of the model was performed through the multiple determination coefficient $\left(R^{2}\right)$, which was 0.9442 (adjusted $R^{2}=0.9052$ ). The given $R^{2}$-value for the reducing sugar content implies that $94.45 \%$

Table 1 ANOVA for the $2^{4-1}$ screening design

\begin{tabular}{lccccc}
\hline Source & $\begin{array}{c}\text { Sum of } \\
\text { Squares }\end{array}$ & df & $\begin{array}{c}\text { Mean } \\
\text { Square }\end{array}$ & $F$-value & $p$-value \\
\hline Model & 6968.88 & 7 & 995.55 & 24.18 & $0.0001^{*}$ \\
$A$-Temperature & 1388.31 & 1 & 1388.31 & 33.72 & $0.0002^{*}$ \\
$B$-Lime loading & 5100.10 & 1 & 5100.10 & 123.88 & $0.0001^{*}$ \\
$C$-Water loading & 19.36 & 1 & 19.36 & 0.4703 & 0.5085 \\
$D$-Time & 0.6006 & 1 & 0.6006 & 0.0146 & 0.9063 \\
$A B$ & 419.43 & 1 & 419.43 & 10.19 & $0.0096^{*}$ \\
$A C$ & 1.01 & 1 & 1.01 & 0.0245 & 0.8787 \\
$A D$ & 40.07 & 1 & 40.07 & 0.9733 & 0.3471 \\
Residual & 411.69 & 10 & 41.17 & & \\
Lack of Fit & 2.20 & 1 & 2.20 & 0.0483 & 0.8310 \\
Pure Error & 409.49 & 9 & 45.50 & & \\
Total Correlation & 7380.56 & 17 & & & \\
\hline Note* * indicate statistical significance in the design $(p-v a l u e s<0.05)$
\end{tabular}

Note: * indicate statistical significance in the design $(p$-values $<0.05)$ 
of the variation between the samples can be attributed to the factors and only $5.55 \%$ of the total variation is not satisfactorily explained by the model.

The principal effects are shown in a Pareto chart (Fig. 1) in which the negative (blue blocks) and positive effects (ochre blocks) of the pretreatment can be distinguished. The length of each bar is proportional to the standardized effect, which is the estimated effect divided by its standard error. This is equivalent to the calculation of the $t$-value for each effect. The $t$-value limit and Bonferroni limit can be used to judge which variables resulted statistically significant, and the results were taken into account for the optimization design.

The response graph shown in Fig. 2 illustrates the mutual interactive effects of the combination of independent variables on reducing sugar content as 3-D surface plots. It was obtained as a function of two factors by holding the others constant.

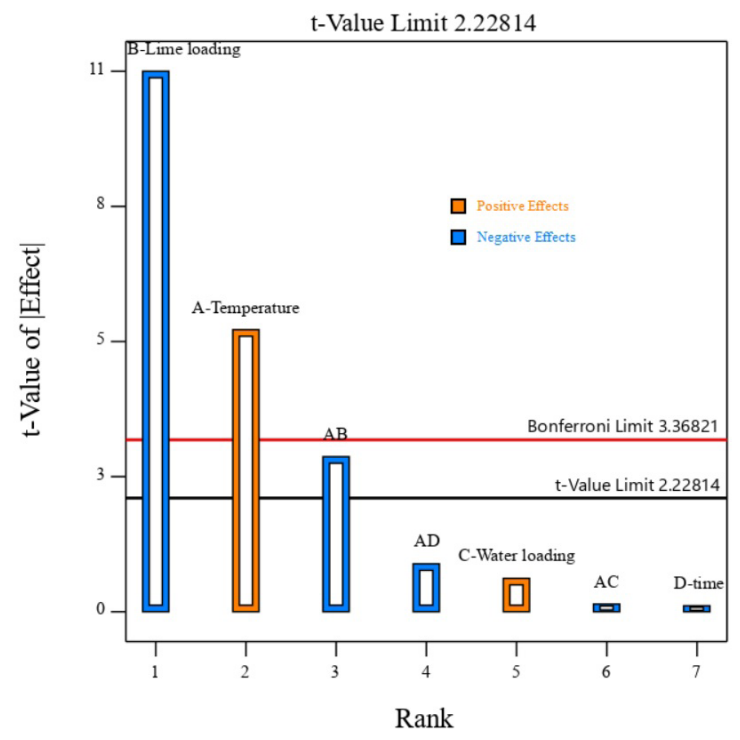

Fig. 1 Pareto chart for screening design

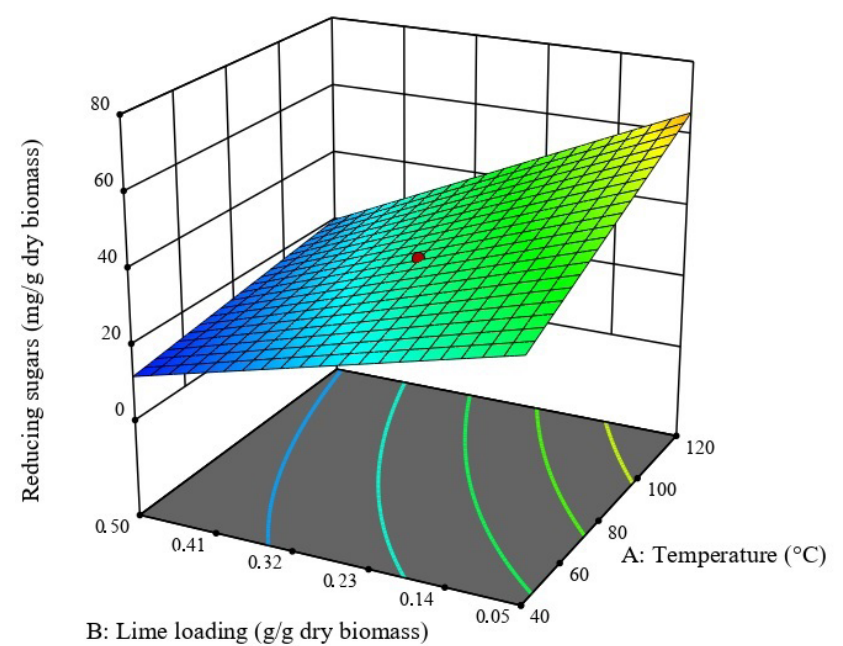

Fig. 2 Surface graph of the screening design for reducing sugars (mg/g)

\subsubsection{Statistical analysis of the optimization design}

Response surface methodology was also applied to determine optimum pretreatment conditions. The second order polynomial equation corresponding to this response is given by Eq. (7).

$$
\begin{aligned}
& \text { Red. Sugars }_{(\mathrm{mg} / \mathrm{g})}=18-1.32 \times A+2362 \times B-21 \times A \times B \\
& +0.02 \times A^{2}+30201 \times B^{2}, \quad R^{2}=0.979
\end{aligned}
$$

When the values for $A$ and $B$ were substituted in the Eq. (7), the predicted responses were obtained. Predicted and experimental values were compared and they were in close agreement (Fig. 3).

It can be observed that the model and temperature $(A)$ were significant. In addition, the multiple determination coefficient obtained from the regression $\left(R^{2}\right)$ was 0.979 and the adjusted $R^{2}$ was 0.8630 . These values ensure a satisfactory adjustment of the theoretical values to the experimental data through this model. The summary of analysis of variance (ANOVA) of the results is presented in Table 2.

Three dimensional response surfaces were plotted to show the interactions between the various parameters in alkaline pretreatment of OTP biomass and to determine the optimum levels of each factor required to obtain maximum response. The effect on reducing sugar content $(\mathrm{mg} / \mathrm{g}$ of dry biomass) in the optimization design is shown in Fig. 4.

\subsection{Validation of the statistical model}

Model equations obtained for the response and the response surface were used to determine optimum $\mathrm{Ca}(\mathrm{OH})_{2}$ pretreatment conditions. Optimal values of each factor that optimized the process response were obtained from a

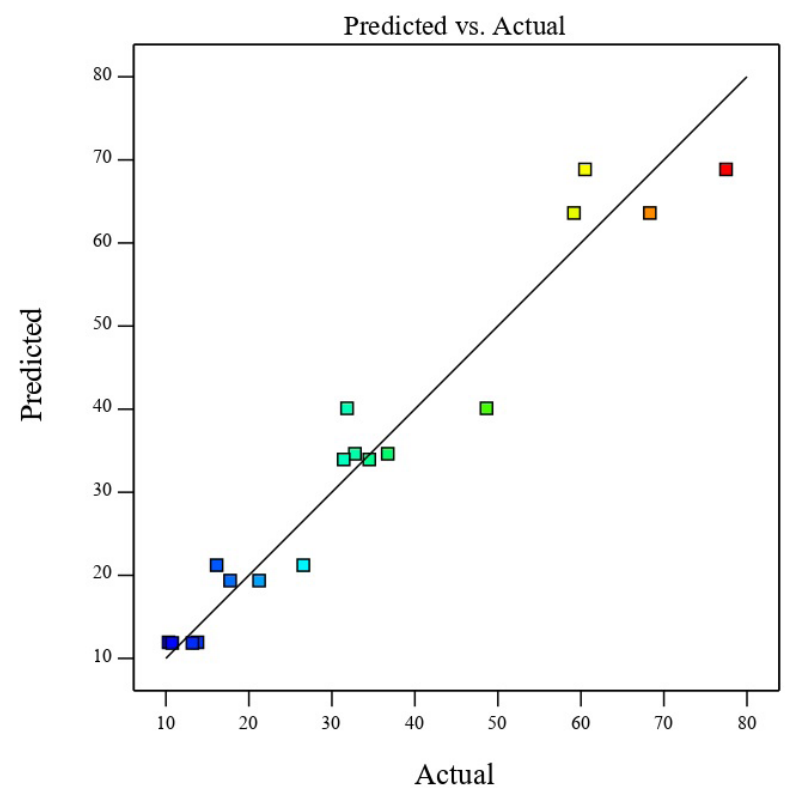

Fig. 3 Predicted vs. actual values optimization design 
Table 2 ANOVA optimization design (Response variable: Reducing sugar content $(\mathrm{mg} / \mathrm{g}))$

\begin{tabular}{lccccc}
\hline Source & $\begin{array}{c}\text { Sum of } \\
\text { Squares }\end{array}$ & df & $\begin{array}{c}\text { Mean } \\
\text { Square }\end{array}$ & $F$-value & $p$-value \\
\hline Block & 1349.08 & 1 & 1349.08 & & \\
Model & 31476.76 & 5 & 6295.35 & 11.08 & $0.0377^{*}$ \\
$A$-Temperature & 21128.36 & 1 & 21128.36 & 37.18 & $0.0089^{*}$ \\
$B$-Lime loading & 2681.38 & 1 & 2681.38 & 4.72 & 0.1182 \\
$A B$ & 4603.62 & 1 & 4603.62 & 8.10 & 0.0653 \\
$A^{2}$ & 3057.83 & 1 & 3057.83 & 5.38 & 0.1031 \\
$B^{2}$ & 667.16 & 1 & 667.16 & 1.17 & 0.3579 \\
Residual & 1704.78 & 3 & 568.26 & & \\
Total Correlation & 34530.62 & 9 & & & \\
\hline
\end{tabular}

Note: * indicate statistical significance in the design $(p$-values $<0.05)$

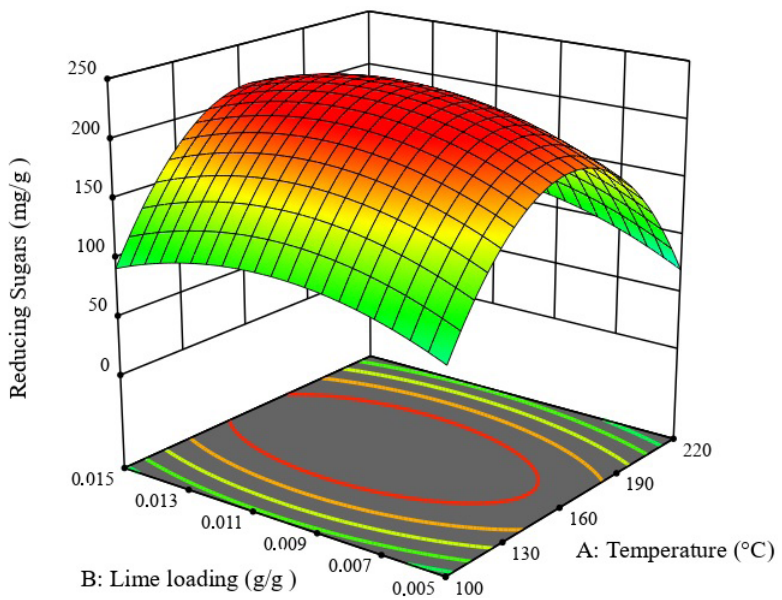

Fig. 4 Response surface graph of the optimization design for reducing sugars $(\mathrm{mg} / \mathrm{g})$

Multi-Objective Numerical Optimization. The optimum conditions obtained from the screening design were $0.05 \mathrm{~g} \mathrm{Ca}(\mathrm{OH})_{2}$ and $20 \mathrm{~g} \mathrm{H}_{2} \mathrm{O}$ per gram of dry biomass at $120{ }^{\circ} \mathrm{C}$ for $2 \mathrm{~h}$, and the optimization design rendered $0.01 \mathrm{~g} \mathrm{Ca}(\mathrm{OH})_{2}$ per gram of dry mass at $160{ }^{\circ} \mathrm{C}$. Table 3 shows predicted and experimental values of the response variable obtained under optimum operating conditions. The predicted response was 69 and $240 \mathrm{mg}$ reducing sugars per gram of dry biomass for the screening and optimization design, respectively. Validation of the results from the model and regression equation was performed in triplicate and the values obtained were in close agreement, thus confirming the optimization process.

Fig. 5 shows a comparative analysis of total and reducing sugar content in raw material and pretreated and hydrolyzed OTP biomass obtained with screening and optimization experimental designs. It can be seen that the percentage of fermentable sugars significantly increased in both cases after application of the alkaline pretreatment.
Table 3 Maximum content of reducing sugars in the prediction models (screening and optimization design)

\begin{tabular}{|c|c|c|c|c|c|}
\hline & \multirow{3}{*}{ 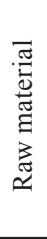 } & \multirow{2}{*}{\multicolumn{2}{|c|}{$\begin{array}{l}\text { A Maximum content in } \\
\text { the screening design } \\
120{ }^{\circ} \mathrm{C}, 0.05 \mathrm{~g} \\
\mathrm{Ca}(\mathrm{OH})_{2} / \mathrm{g} \text { of dry mass }\end{array}$}} & \multirow{2}{*}{\multicolumn{2}{|c|}{$\begin{array}{l}\begin{array}{l}\text { B Maximum content in } \\
\text { the optimization design }\end{array} \\
160{ }^{\circ} \mathrm{C}, 0.01 \mathrm{~g} \\
\mathrm{Ca}(\mathrm{OH})_{2} / \mathrm{g} \text { of dry mass }\end{array}$}} \\
\hline & & & & & \\
\hline & & $\begin{array}{l}\text { Predicted } \\
\text { response }\end{array}$ & $\begin{array}{l}\text { Exp. } \\
\text { response }\end{array}$ & $\begin{array}{l}\text { Predicted } \\
\text { response }\end{array}$ & $\begin{array}{l}\text { Exp. } \\
\text { response }\end{array}$ \\
\hline $\begin{array}{l}\text { Reducing } \\
\text { sugars } \\
(\mathrm{mg} / \mathrm{g})\end{array}$ & $\stackrel{\text { ֻे }}{=}$ & 68.99 & 68.32 & 240 & 220 \\
\hline Diff & & \multicolumn{2}{|c|}{$\mathbf{A}: 1 \%$} & \multicolumn{2}{|c|}{ B: $8 \%$} \\
\hline
\end{tabular}

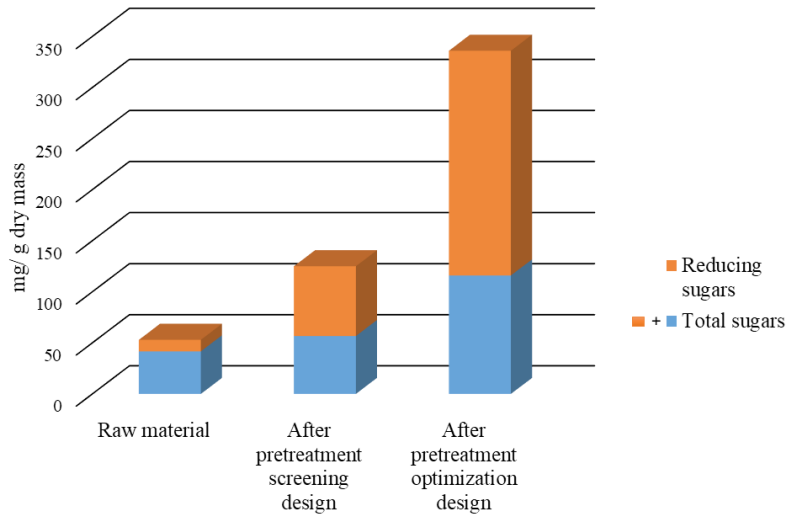

Fig. 5 Comparative graph of maximum sugar content

The reducing sugar content increased 500\% under optimal conditions of the screening test and $1800 \%$ during the optimization stage. Other authors have obtained similar results with the same raw material. Saha and Cotta [28] assayed similar conditions to ours, pretreating rice hulls with $\mathrm{Ca}(\mathrm{OH})_{2}$ (a lime loading of $100 \mathrm{mg} / \mathrm{g}, 121{ }^{\circ} \mathrm{C}, 1 \mathrm{~h}$ ) and three enzymes (cellulase, hemicellulase and $\beta$-glucosidase) for hydrolysis $\left(45^{\circ} \mathrm{C}, \mathrm{pH} 5,72 \mathrm{~h}\right)$, obtaining $154 \mathrm{mg}$ sugars per gram of substrate. Mateo et al. [29] carried out pretreatment with $2 \% \mathrm{H}_{2} \mathrm{SO}_{4}$ at $120{ }^{\circ} \mathrm{C}$ for $90 \mathrm{~min}$ and obtained $12.4 \mathrm{~g} / 1$ of total sugars from OTP residues, similar to the maximum reached in our study (10.5 g/l).

\subsection{Effects of alkaline pretreatment on OTP biomass}

SEM was proposed to observe the superficial changes in OTP biomass after alkaline pretreatment. Fig. 6 (a) and (b) shows images of raw and pretreated olive tree pruning residues, respectively. It can be observed that prior to pretreatment the material presented structures that are typical of olive leaves, called trichomes and also known as foliar plates, that constitute part of the epidermis and play a protection role against plagues and diseases [30]. In Fig. 6 (b) it can be seen how the original structures changed, showing holes and interstices produced by the 


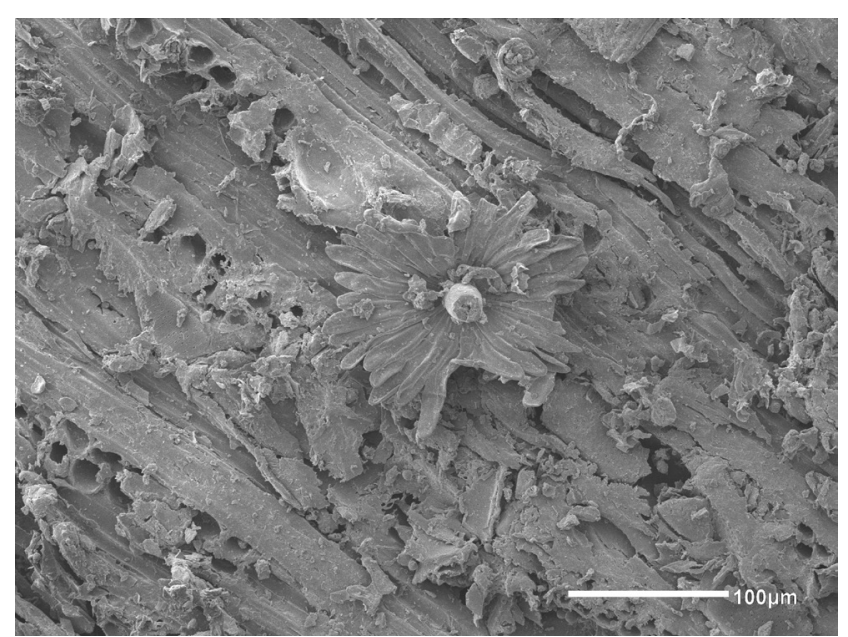

(a)

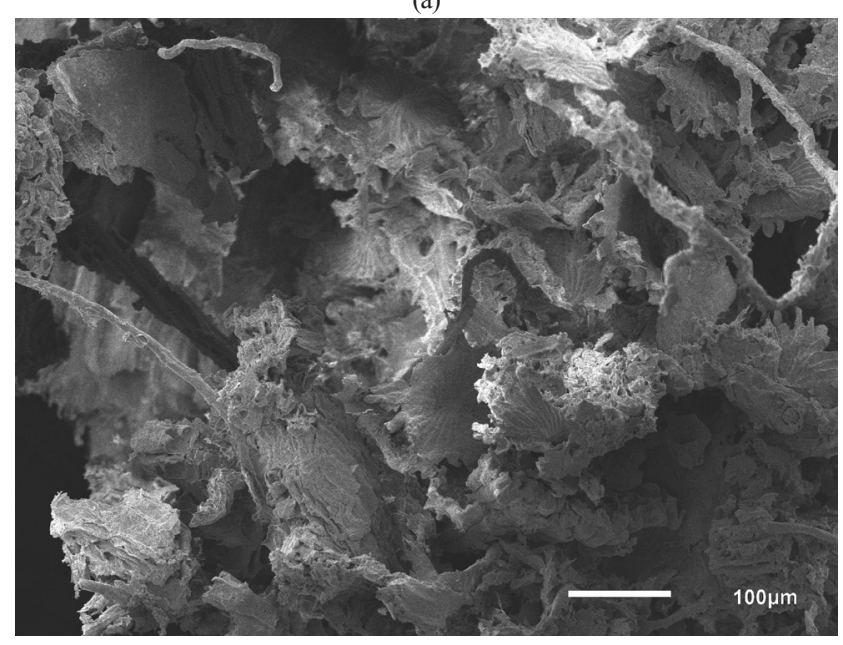

(b)

Fig. 6 SEM images of OTP biomass samples before (a) and after (b) treatment with $\mathrm{Ca}(\mathrm{OH})_{2}$

alkaline pretreatment. The peeling effect of alkaline pretreatment is evident, and results in a morphological change in the OTP biomass surface. Delignification leads to the formation of holes in the structure of the cell wall and therefore, its surface seems more fragile when compared with the untreated sample [31].

Fig. 7 shows the general mass balance and lignocellulosic composition of OTP residues and hydrolyzed solid OTP (stream 4) after pretreatment-hydrolysis stages. It can be observed that the lignin content is almost unaffected, whereas cellulose and hemicellulose changed considerably after pretreatment and hydrolysis; both components were hydrolyzed (see streams 3 and 4 of both balances). The greatest change occurs in hemicellulose, which can be expected during pretreatment with calcium hydroxide since it releases the acetyl groups of hemicellulose [32]. The low percentage of solubilized cellulose can be attributed to the fact that alkaline pretreatments do not typically act on this polymer. The minor lignin removal can be ascribed to the low solubility of hardwood lignins in alkaline solutions due to their structural characteristics. Brandt et al. [32] studied the chemical composition of different lignocellulosic biomasses and the chemical effect on delignification, and hence on biomass deconstruction. The lignin composition of softwoods, hardwoods and grasses greatly varies; in softwoods it mostly consists of guaiacyl (G) units, while in hardwoods it also contains a large number of syringyl (S) units. G units are more likely to be cross-linked at the $\mathrm{C} 5$ position of the ring during delignification. In contrast, the C5 position in $\mathrm{S}$ units is occupied, and therefore it cannot participate in substitution reactions. Consequently, it cannot be hydrolyzed by acids or bases, making delignification of hardwoods more difficult than softwoods [32]. Under the optimum experimental conditions, it was revealed that solubilization of hemicellulose and cellulose prevailed over lignin removal.

\section{GENERAL MASS BALANCE}
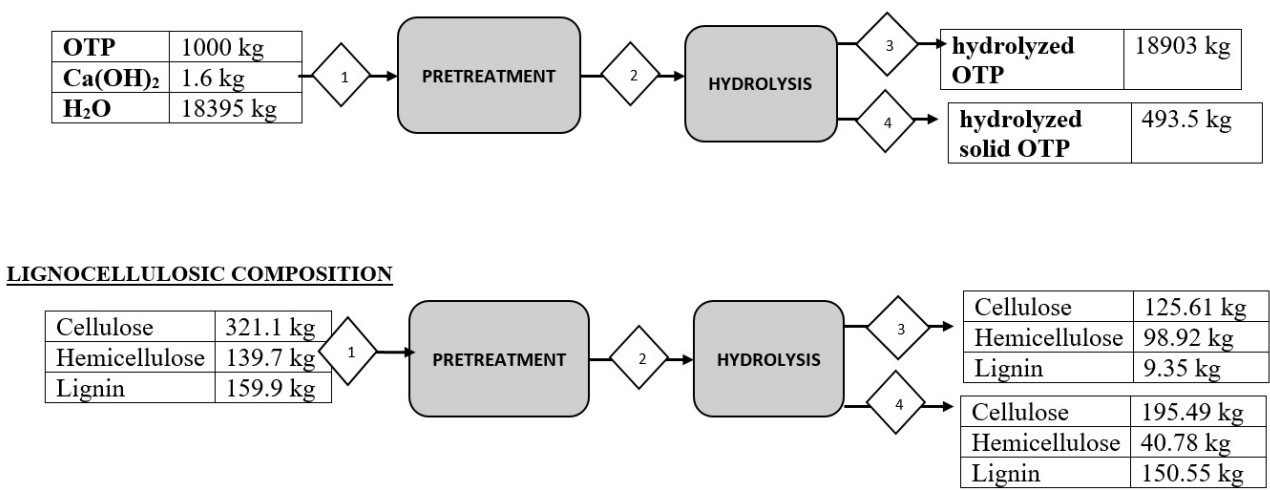

Fig. 7 General mass balance and lignocellulosic components under optimum experimental conditions 


\subsection{Bioethanol production}

The ethanol concentration after 3 days of fermentation was $1.42 \pm 0.03 \mathrm{~g} / 1$. The notable performance of this native yeast with respect to the bioethanol production is remarkable. Initial sugars concentration was $10.5 \mathrm{~g} / 1$ and the sugars after fermentation was $6.5 \mathrm{~g} / \mathrm{l}$. The yield was 0.35 grams of ethanol per gram of consumed sugar. The performance favorably compares with other studies using the same feedstock. Moya et al. [33] obtained $0.33 \mathrm{~g}$ of ethanol per gram of sugar, after acid pretreatment using $\mathrm{H}_{2} \mathrm{SO}_{4}$, Fonseca et al. [34] reported a yield of $0.20 \mathrm{~g}$ of ethanol per gram of sugar from olive tree wood pretreated with sequentially alkaline/acid system $\left(\mathrm{NaOH} / \mathrm{H}_{2} \mathrm{SO}_{4}\right)$ and Carvalho et al. [35] obtained $0.4 \mathrm{~g}$ of ethanol per gram of sugar after alkaline pretreatment in eucalypt wood using $\mathrm{NaOH}$. Nevertheless, further research is necessary to optimize this stage of the bioethanol production process. Table 4 shows a comparison of the ethanol values obtained in the present study with those reported by other authors using various lignocellulosic residues and different pretreatments [36-39].

\section{Conclusions}

The amount of fermentable sugars obtained from Olive Tree Pruning (OTP) biomass treated with calcium hydroxide makes it a promising raw material for bioethanol production.

Scanning electron microscopy together with the crystallinity index of samples pretreated with $\mathrm{Ca}(\mathrm{OH})_{2}$ showed the peeling effect of the lime, which resulted in morphological changes of the solid surface favoring the subsequent hydrolysis step.

Statistical tools allowed building a mathematical model that governed this alkaline pretreatment and the operating conditions that yielded maximum fermentable sugar content. The sugar concentration increased $1800 \%$ compared with the raw material allowing a production of $28.4 \mathrm{~g}$ ethanol from $1 \mathrm{~kg}$ of untreated solids.

\section{References}

[1] Barros, V. R., Field, C. B., Dokken, D. J., Mastrandrea, M. D., Mach, K. J. (eds.) "Climate Change 2014 - Impacts, Adaptation and Vulnerability:Part B: Regional Aspects", Cambridge University Press, Cambridge, UK, 2014. https://doi.org/10.1017/CBO9781107415386

[2] Scarlat, N., Dallemand, J. F., Motola, V., Monforti-Ferrario, F. "Bioenergy production and use in Italy: Recent developments, perspectives and potential", Renewable Energy 57, pp. 448-461, 2013. https://doi.org/10.1016/j.renene.2013.01.014
Table 4 Comparative analysis of ethanol production from different lignocellulosic residues

\begin{tabular}{|c|c|c|c|c|}
\hline Biomass & $\begin{array}{l}\text { Pretreatment } \\
\text { conditions }\end{array}$ & $\begin{array}{l}\text { Sugars } \\
(\mathrm{mg} / \mathrm{g})\end{array}$ & $\begin{array}{l}\text { Ethanol } \\
\text { (g EtOH/g } \\
\text { biomass) }\end{array}$ & Ref. \\
\hline $\begin{array}{l}\text { Olive tree } \\
\text { Pruning }\end{array}$ & $\begin{array}{c}1 \%(\mathrm{v} / \mathrm{v}) \mathrm{H}_{2} \mathrm{SO}_{4} \\
15 \%(\mathrm{w} / \mathrm{v}) \\
164{ }^{\circ} \mathrm{C} \\
10 \mathrm{~min}\end{array}$ & 126 & 0.13 & {$[37]$} \\
\hline Barley straw & $\begin{array}{c}\mathrm{NaOH}(0.58 \mathrm{M}) \\
10 \%(\mathrm{w} / \mathrm{v}) \\
87^{\circ} \mathrm{C}\end{array}$ & 163 & 0.05 & {$[36]$} \\
\hline $\begin{array}{l}\text { Sugarcane } \\
\text { bagasse pith }\end{array}$ & $\begin{array}{c}1 \%(\mathrm{v} / \mathrm{v}) \mathrm{H}_{2} \mathrm{SO}_{4} \\
10 \%(\mathrm{w} / \mathrm{v}) \\
121{ }^{\circ} \mathrm{C} \\
90 \mathrm{~min} \\
1.5 \mathrm{bar}\end{array}$ & 537 & 0.25 & {$[38]$} \\
\hline $\begin{array}{l}\text { Hardy sugar } \\
\text { cane }\end{array}$ & $\begin{array}{c}0.5 \% \mathrm{NaOH} \\
5 \%(\mathrm{w} / \mathrm{v}) \\
30 \mathrm{~min}\end{array}$ & 185 & 0.03 & [39] \\
\hline $\begin{array}{l}\text { Olive Tree } \\
\text { Pruning }\end{array}$ & $\begin{array}{c}1 \% \text { of } \mathrm{Ca}(\mathrm{OH})_{2} \\
5 \%(\mathrm{w} / \mathrm{v}) \\
120 \mathrm{~min} \\
160{ }^{\circ} \mathrm{C}\end{array}$ & 220 & 0.03 & $\begin{array}{l}\text { This } \\
\text { study }\end{array}$ \\
\hline
\end{tabular}

According to these results, the Olive Tree Pruning biomass could yield $85 \mathrm{~kg} /$ ha of bioethanol. Our findings are promising for a future bioethanol production from this cheap and abundant material and highlight the importance to recycle and valorize waste.

\section{Aknowledgement}

The present study was partially financed by the following Argentine institutions: National Scientific and Technical Research Council (CONICET), Universidad Nacional de San Juan and SECITI (Secretary of Science, Technology and Innovation) of the San Juan province. The authors would like to acknowledge CREA (civil association of agricultural entrepreneurs) for their collaboration and providing the OTP residue used in this study.

[3] Negro, M. J., Manzanares, P., Ruiz, E., Castro, E., Ballesteros, M. "Chapter 3 - The biorefinery concept for the industrial valorization of residues from olive oil industry", In: Galanakis, C. M. (ed.) Olive Mill Waste: Recent Advances for Sustainable Management, Academic Press, Cambridge, MA, USA, 2017, pp. 57-78. https://doi.org/10.1016/b978-0-12-805314-0.00003-0

[4] Stephen, J. L., Periyasamy, B. "Innovative developments in biofuels production from organic waste materials: A review", Fuel, 214, pp. 623-633, 2018. https://doi.org/10.1016/j.fuel.2017.11.042 
[5] Tomás-Pejó, E., Oliva, J. M., Ballesteros, M. "Realistic approach for full-scale bioethanol production from lignocellulose: a review", Journal on Scientific \& Industrial Research, 67(11), pp. 874-884, 2008. [online] Available at: http://nopr.niscair.res.in/ handle/123456789/2416 [Accessed: 23 June 2021]

[6] Romero-García, J. M., Niño, L., Martínez-Patiño, C., Álvarez, C., Castro, E., Negro, M. J. "Biorefinery based on olive biomass. State of the art and future trends", Bioresource Technology, 159, pp. 421-432, 2014.

https://doi.org/10.1016/j.biortech.2014.03.062

[7] Aditiya, H. B., Mahlia, T. M. I., Chong, W. T., Nur, H., Sebayang, A. H. "Second generation bioethanol production: A critical review", Renewable and Sustainable Energy Reviews 66, pp. 631-653, 2016.

https://doi.org/10.1016/j.rser.2016.07.015

[8] Zabed, H., Sahu, J. N., Boyce, A. N., Faruq, G. "Fuel ethanol production from lignocellulosic biomass: An overview on feedstocks and technological approaches", Renewable and Sustainable Energy Reviews, 66, pp. 751-774, 2016.

https://doi.org/10.1016/j.rser.2016.08.038

[9] Agustini, L., Efiyanti, L., Faulina, S. A., Santoso, E. "Isolation and Characterization of Cellulase- and Xylanase Producing Microbes Isolated from Tropical Forests in Java and Sumatra", International Journal and Environment and Bioenergy, 3(3), pp. 154-167, 2012. [online] Available at: http://www.modernscientificpress.com/ Journals/ViewArticle.aspx?gkN1Z6Pb60HNQPymfPQ1ZM2Qz BATUXAyEhQZJVFyB5jx ACLp2DSn8X3BE2yz4Gxm [Accessed: 23 June 2021]

[10] Taha, M., Foda, M., Shahsavari, E., Aburto-Medina, A., Adetutu, E., Ball, A. "Commercial feasibility of lignocellulose biodegradation: possibilities and challenges", Current Opinion in Biotechnology, 38, pp. 190-197, 2016. https://doi.org/10.1016/j.copbio.2016.02.012

[11] Gupta, A., Verma, J. P. "Sustainable bio-ethanol production from agro-residues: A review", Renewable and Sustainable Energy Reviews, 41, pp. 550-567, 2015. https://doi.org/10.1016/j.rser.2014.08.032

[12] Haldar, D., Purkait, M. K. "A review on the environment-friendly emerging techniques for pretreatment of lignocellulosic biomass: Mechanistic insight and advancements", Chemosphere, 264(Part 2), Article number: 128523, 2021. https://doi.org/10.1016/j.chemosphere.2020.128523

[13] Conde-Mejía, C., Jiménez-Gutiérrez, A., El-Halwagi, M. "A comparison of pretreatment methods for bioethanol production from lignocellulosic materials", Process Safety and Environmental Protection, 90(3), pp. 189-202, 2012.

https://doi.org/10.1016/j.psep.2011.08.004

[14] Di Girolamo, G., Bertin, L., Capecchi, L., Ciavatta, C., Barbanti, L. "Mild alkaline pre-treatments loosen fibre structure enhancing methane production from biomass crops and residues", Biomass and Bioenergy, 71, pp. 318-329, 2014. https://doi.org/10.1016/j.biombioe.2014.09.025

[15] Chen, B.-Y., Chen, S.-W., Wang, H.-T. "Use of different alkaline pretreatments and enzyme models to improve low-cost cellulosic biomass conversion", Biomass and Bioenergy, 39, pp. 182-191, 2012.

https://doi.org/10.1016/j.biombioe.2012.01.012
[16] Park, J., Shiroma, R., Al-Haq, M. I., Zhang, Y., Ike, M., Arai-Sanoh, Y., Ida, A., Kondo, M., Tokuyashu, K. "A novel lime pretreatment for subsequent bioethanol production from rice straw - Calcium capturing by carbonation (CaCCO) process", Bioresoure Technology, 101(17), pp. 6805-6811, 2010. https://doi.org/10.1016/j.biortech.2010.03.098

[17] Sierra, R., Granda, C., Holtzapple, M. T. "Short-term lime pretreatment of poplar wood", Biotechnology Progress, 25(2), pp. 323-332, 2009. https://doi.org/10.1002/btpr.83

[18] Jiang, D., Ge, X., Zhang, Q., Zhou, X., Chen, Z., Keener, H., Li, Y. "Comparison of sodium hydroxide and calcium hydroxide pretreatments of giant reed for enhanced enzymatic digestibility and methane production", Bioresoure Technology, 244(Part 1), pp. 1150-1157, 2017.

https://doi.org/10.1016/j.biortech.2017.08.067

[19] Pulido, H. G., de la Vara Salazar, R. "Análisis y diseño de experimentos" (Analysis and design of experiments), McGraw-Hill, CDMX, Mexico, 2003. (in Spanish)

[20] ASTM International "ASTM D4442-92(2003) Standard Test Methods for Direct Moisture Content Measurement of Wood and Wood-Base Materials", ASTM International, West Conshohocken, PA, USA, 2003. https://doi.org/10.1520/D4442-92R03

[21] ASTM International "ASTM D1102-84(2021) Standard Test Method for Ash in Wood", ASTM International, West Conshohocken, PA, USA, 2021.

https://doi.org/10.1520/D1102-84R21

[22] ASTM International "ASTM E872-82(2019) Standard Test Method for Volatile Matter in the Analysis of Particulate Wood Fuels", ASTM International, West Conshohocken, PA, USA, 2019. https://doi.org/10.1520/E0872-82R19

[23] Dubois, M., Gilles, K., Hamilton, J. K., Rebers, P. A., Smith, F. "A Colorimetric Method for the Determination of Sugars", Nature, 168(4265), p. 167, 1951. https://doi.org/10.1038/168167a0

[24] Carlson, R. "Design of Experiments, Principles and Applications", Journal of Chemometrics, 15(5), pp. 495-496, 2001. https://doi.org/10.1002/cem.686

[25] Miller, G. L. "Use of Dinitrosalicylic Acid Reagent for Determination of Reducing Sugar", Analytical Chemistry, 31(3), pp. 426-428, 1959. https://doi.org/10.1021/ac60147a030

[26] Cai, J., He, Y., Yu, X., Banks, S. W., Yang, Y., Zhang, X., Yu, Y., Liu, R., Bridgwater, A. V. "Review of physicochemical properties and analytical characterization of lignocellulosic biomass", Renewable and Sustainable Energy Reviews, 76, pp. 309-322, 2017. https://doi.org/10.1016/j.rser.2017.03.072

[27] Van Soest, P. J., Robertson, J. B., Lewis, B. A. "Methods for Dietary Fiber, Neutral Detergent Fiber, and Nonstarch Polysaccharides in Relation to Animal Nutrition", Journal of Dairy Science, 74(10), pp. 3583-3597, 1991. https://doi.org/10.3168/jds.S0022-0302(91)78551-2

[28] Saha, B. C., Cotta, M. A. "Lime pretreatment, enzymatic saccharification and fermentation of rice hulls to ethanol", Biomass and Bioenergy, 32(10), pp. 971-977, 2008. https://doi.org/10.1016/j.biombioe.2008.01.014 
[29] Mateo, S., Roberto, I. C., Sánchez, S., Moya, A. J. "Detoxification of hemicellulosic hydrolyzate from olive tree pruning residue", Industrial Crops and Products, 49, pp. 196-203, 2013. https://doi.org/10.1016/j.indcrop.2013.04.046

[30] International Olive Oil Council "World olive encyclopaedia", World Olive Council, Madrid, Spain, 1996.

[31] Fromm, J., Rockel, B., Lautner, S., Windeisen, E., Wanner, G. "Lignin distribution in wood cell walls determined by TEM and backscattered SEM techniques", Journal of Structural Biology, 143(1), pp. 77-84, 2003. https://doi.org/10.1016/s1047-8477(03)00119-9

[32] Brandt, A., Gräsvik, J., Hallett, J. P., Welton, T. "Deconstruction of lignocellulosic biomass with ionic liquids", Green Chemistry 15(3), pp. 550-583, 2013. https://doi.org/10.1039/c2gc36364j

[33] Moya, A. J., Mateo, S., Puentes, J. G., Fonseca, B. G., Roberto, I. C., Sánchez, S. "Comparing Bioalcohols Production from Olive Pruning Biomass by Biotechnological Pathway with Candida guilliermondii and Pichia stipitis", Waste and Biomass Valorization, 7(6), pp. 1369-1375, 2016. https://doi.org/10.1007/s12649-016-9531-3

[34] Fonseca, B. G., Mateo, S., Roberto, I. C., Sánchez, S., Moya, A. J. "Bioconversion in batch bioreactor of olive-tree pruning biomass optimizing treatments for ethanol production", Biochemical Engineering Journal, 164, Article number: 107793, 2020. https://doi.org/10.1016/j.bej.2020.107793
[35] Carvalho, D. M., Queiroz, J. H., Colodette, J. L. "Assessment of alkaline pretreatment for the production of bioethanol from eucalyptus, sugarcane bagasse and sugarcane straw", Industrial Crops and Products, 94, pp. 932-941, 2016. https://doi.org/10.1016/j.indcrop.2016.09.069

[36] Han, M., Kang, K. E., Kim, Y., Choi, G.-W. "High efficiency bioethanol production from barley straw using a continuous pretreatment reactor", Process Biochemistry, 48(3), pp. 488-495, 2013. https://doi.org/10.1016/j.procbio.2013.01.007

[37] Fernandes-Klajn, F., Romero-García, J. M., Díaz, M. J., Castro, E. "Comparison of fermentation strategies for ethanol production from olive tree pruning biomass", Industrial Crops and Products, 122, pp. 98-106, 2018 https://doi.org/10.1016/j.indcrop.2018.05.063

[38] Sritrakul, N., Nitisinprasert, S., Keawsompong, S. "Evaluation of dilute acid pretreatment for bioethanol fermentation from sugarcane bagasse pith", Agriculture and Natural Resources, 51(6), pp. 512-519, 2017. https://doi.org/10.1016/j.anres.2017.12.006

[39] Muthuvelu, K. S., Rajarathinam, R., Kanagaraj, L. P., Ranganathan, R. V., Dhanasekaran, K, Manickam, N. K. "Evaluation and characterization of novel sources of sustainable lignocellulosic residues for bioethanol production using ultrasound-assisted alkaline pre-treatment", Waste Management, 87, pp. 368-374, 2019.

https://doi.org/10.1016/j.wasman.2019.02.015 